4. Behr J, Bonella F, Bonnet R, Gläser S, Grohé C, Günther A, Koschel D, Kreuter M, Kirsten D, Krögel C, et al. [Position paper: significance of the forced vital capacity in idiopathic pulmonary fibrosis] Pneumologie 2015;69:455-458.

5. Bodlet A, Maury G, Jamart J, Dahlqvist C. Influence of radiological emphysema on lung function test in idiopathic pulmonary fibrosis. Respir Med 2013;107:1781-1788.

6. Jankowich MD, Rounds S. Combined pulmonary fibrosis and emphysema alters physiology but has similar mortality to pulmonary fibrosis without emphysema. Lung 2010;188:365-373.

7. Kurashima K, Takayanagi N, Tsuchiya N, Kanauchi T, Ueda M, Hoshi T, Miyahara $Y$, Sugita $Y$. The effect of emphysema on lung function and survival in patients with idiopathic pulmonary fibrosis. Respirology 2010;15:843-848.

8. King TE, Jr, Albera C, Bradford WZ, Costabel U, Hormel P, Lancaster L, Noble PW, Sahn SA, Szwarcberg J, Thomeer M, et al.;
INSPIRE Study Group. Effect of interferon gamma-1b on survival in patients with idiopathic pulmonary fibrosis (INSPIRE): a multicentre, randomised, placebo-controlled trial. Lancet 2009; 374:222-228.

9. Raghu G, Brown KK, Bradford WZ, Starko K, Noble PW, Schwartz DA, King TE, Jr; Idiopathic Pulmonary Fibrosis Study Group. A placebo-controlled trial of interferon gamma- $1 \mathrm{~b}$ in patients with idiopathic pulmonary fibrosis. N Engl J Med 2004;350:125-133.

10. Cottin V, Hansell DM, Sverzellati N, Weycker D, Antoniou KM, Atwood M, Oster G, Kirchgaessler K-U, Collard HR, Wells AU. Effect of emphysema extent on serial lung function in patients with idiopathic pulmonary fibrosis. Am J Respir Crit Care Med 2017; 196:1162-1171.

Copyright @ 2017 by the American Thoracic Society

\title{
Picornavectors
}

\section{Viruses That Spread Bacteria}

Rhinoviruses (RVs) cause more infections than any other pathogen, and the reason for their success is multifactorial. From a molecular perspective, RVs replicate rapidly, inhibit host interferon responses, and mutate quickly (one mutation per $10^{4}$ bases, or about one mutation per virus) to adapt to local host conditions (1). These properties are shared with other picornaviruses. RVs are distinct in more than 160 types, which is an effective strategy to circumvent neutralizing antibodies. Furthermore, there are at least 20 different RV types that circulate in any given community (2), so chances are good that individuals will be susceptible to at least one of the current circulating viruses. Furthermore, as the seasons change, so do the prevalent RVs. RV infections also induce behaviors such as rhinorrhea, sneezing, and coughing that lead to transmission. In this issue of the Journal, Karppinen and colleagues (pp. 1172-1180) show that RV infections also promote spread of Streptococcus pneumoniae (3). These data suggest we might think of these viruses as very small vectors; in other words, picornavectors.

To describe the effect of RV infection on acquisition and transmission of pneumococci, Karppinen and colleagues studied 29 families with at least two children. When a respiratory illness was recognized, family members provided daily symptom diaries together with twice-weekly swabs to enable tracking of the spread of both RVs and pneumococci. Molecular viral diagnostics were used to analyze the RV types, and the bacteria were analyzed by antigen detection and by culture. A subset of pneumococcal isolates was sequenced to determine whether the isolates from within a family were likely to represent transmission. Rates of pneumococcal acquisition from the community or from the family were calculated for adults and for children. The main findings were that $\mathrm{RV}$ infection increased the rate of pneumococcal acquisition in children from the community (4.3-fold increase), and that the effects were even greater on pneumococcal acquisition from the family (14.8-fold increase). The authors conclude that RV infections within families facilitates both community acquisition and within-family transmission of S. pneumoniae.

Originally Published in Press as DOI: 10.1164/rccm.201706-1073ED on June 19, 2017
There are a few limitations to the study findings that were acknowledged by the authors. Nasal swabs were obtained at home by parents, and it is possible this method underestimates bacterial colonization from other airway locations (4). In addition, the concept that viral infections could promote acquisition of pneumococcal colonization was first introduced by transmission studies conducted in the 1970s (5) and reaffirmed by more recent studies $(6,7)$. However, the current study adds new information through the use of frequent sampling together with molecular methods to type both the viruses and the bacteria, and convincingly proves these concepts.

Still, it remains to be determined how RV infections lead to new acquisition of pneumococcal colonization. In some cases, the pneumococci colonization may preexist in different parts of the airway (e.g., adenoidal tissue), and RV infections may facilitate the expression of pneumococcus in the nose. Furthermore, are the bacteria spread by the same mechanisms (aerosols and contact with fomites) that lead to viral transmission? Also, are viruses and bacteria transmitted and acquired at the same time, or in a stepwise process? Answers to these questions may provide insights into interventions to interrupt acquisition and spread of pneumococcal colonization.

Children are major vectors for infectious diseases, including viral respiratory illnesses such as influenza (8) and RV (9). In contrast, casual contact between adults is an inefficient way to spread viruses. For example, Peltola and colleagues studied transmission of RVs within families and found that young children were more likely to transmit the infection to adults than vice versa (9). In their current study, acquisition of pneumococcus was more likely to occur in families with many children, or in children who attended day care. Thus, children are most likely to transmit RV infections, and also are more likely to spread colonization with $S$. pneumoniae. For adults, the prevalence of $S$. pneumoniae and acquisition rates in adults were both quite low. The reasons for the age-related differences in pathogen transmission are likely to be multifactorial, and include better hygiene and mature innate and adaptive immune responses to both bacteria and viruses.

What are the implications of RV infections facilitating the spread of S. pneumoniae? Could this be of mutual benefit for the 
virus and the bacteria? One mechanism to consider is that RV infections that are accompanied by detection of bacterial pathogens such as $S$. pneumoniae are more likely to be symptomatic compared with RV infections without bacterial detection (5). Because symptomatic infections are more readily transmitted than asymptomatic infections $(9,10)$, cotransmission of RV and S. pneumonia (or perhaps other bacterial pathogens) could increase the probability of secondary symptomatic illnesses, and in turn could promote more efficient transmission of RV infection to other contacts.

In addition increasing the probability of symptomatic respiratory illnesses, acquisition of both RV infection and pneumococcus could increase the risk for bacterial complications of viral respiratory infections, such as otitis media, sinusitis, and pneumonia. As a consequence, treatments that prevent or lessen the severity of RV infections could secondarily reduce the spread of pneumococcal colonization and these secondary infectious complications. As new therapies or vaccines targeting RV infections progress from preclinical investigations into clinical trials, it will be of great interest to determine whether inhibition of these picornavectors for pneumococcal transmission have benefits to respiratory health that extend beyond inhibition of $\mathrm{RV}$ infection.

\author{
Author disclosures are available with the text of this article at \\ www.atsjournals.org \\ James E. Gern, M.D. \\ Department of Pediatrics \\ and \\ Department of Medicine \\ University of Wisconsin School of Medicine and Public Health \\ Madison, Wisconsin
}

\section{References}

1. Gern JE, Palmenberg AC. Rhinoviruses. In: Knipe DM, Howley PM, editors. Field's virology. Philadelphia: Lippincott Williams \& Wilkins; 2013.

2. Olenec JP, Kim WK, Lee WM, Vang F, Pappas TE, Salazar LE, Evans MD, Bork J, Roberg K, Lemanske RF, Jr, et al. Weekly monitoring of children with asthma for infections and illness during common cold seasons. $J$ Allergy Clin Immunol 2010;125:1001-1006.e1.

3. Karppinen S, Teräsjärvi J, Auranen K, Schuez-Havupalo L, Siira L, He Q, Waris M, Peltola V. Acquisition and transmission of Streptococcus pneumoniae are facilitated during rhinovirus infection in families with children. Am J Respir Crit Care Med 2017;196:1172-1180.

4. Hendley JO, Sande MA, Stewart PM, Gwaltney JM, Jr. Spread of Streptococcus pneumoniae in families. I. Carriage rates and distribution of types. J Infect Dis 1975;132:55-61.

5. Gwaltney JM, Jr, Sande MA, Austrian R, Hendley JO. Spread of Streptococcus pneumoniae in families: Il: relation of transfer of $S$. pneumoniae to incidence of colds and serum antibody. $J$ Infect Dis 1975;132:62-68.

6. Kloepfer KM, Lee WM, Pappas TE, Kang TJ, Vrtis RF, Evans MD, Gangnon RE, Bochkov YA, Jackson DJ, Lemanske RF, Jr, Gern JE. Detection of pathogenic bacteria during rhinovirus infection is associated with increased respiratory symptoms and asthma exacerbations. J Allergy Clin Immunol 2014;133:1301-1307 e1303.

7. Diavatopoulos DA, Short KR, Price JT, Wilksch JJ, Brown LE, Briles DE, Strugnell RA, Wijburg OL. Influenza A virus facilitates Streptococcus pneumoniae transmission and disease. FASEB J 2010;24:1789-1798.

8. Reichert TA, Sugaya N, Fedson DS, Glezen WP, Simonsen L, Tashiro M. The Japanese experience with vaccinating schoolchildren against influenza. N Engl J Med 2001;344:889-896.

9. Peltola V, Waris M, Osterback R, Susi P, Ruuskanen O, Hyypiä T. Rhinovirus transmission within families with children: incidence of symptomatic and asymptomatic infections. $J$ Infect Dis 2008;197:382-389.

10. Jennings LC, Dick EC. Transmission and control of rhinovirus colds. Eur J Epidemiol 1987;3:327-335.

\section{The Debate Should Now Be Over: Simplified Cardiorespiratory Sleep Tests Are a Reliable, Cost-Saving Option for Diagnosing Obstructive Sleep Apnea}

Obstructive sleep apnea (OSA) is a highly prevalent condition that is associated with significant morbidity and mortality. Its prevalence is rising worldwide $(1,2)$ because of increasing rates of obesity (3) and aging population demographics. Globally, there is a substantial burden of undiagnosed and untreated OSA, particularly in heavily populated, underresourced regions of the world such as in Asia, Africa, and South America, but also within subpopulations of economically developed countries, including in rural and remote regions and among indigenous populations and those experiencing socioeconomic disadvantage.

Laboratory polysomnography (PSG) is the traditional, gold standard method for diagnosing sleep-disordered breathing. In large part, this is historical, as OSA was first described by neurologists

Originally Published in Press as DOI: 10.1164/rccm.201706-1199ED on June 29, 2017 who used detailed physiological studies that included electroencephalography to identify sleep $(4,5)$. However, laboratory PSG is labor-intensive and relatively complex and expensive, and its availability is therefore limited. As a result, attention has turned toward the development of simplified sleep study methods such as with type 3 devices, which record at least four cardiorespiratory signals without electrophysiological signals to measure sleep, and type 4 devices, which have only one or two recording channels, one of which is usually oximetry.

Initially, most studies evaluating the performance of limitedchannel sleep studies focused on defining their diagnostic accuracy compared with PSG (6). Although these studies have demonstrated good to very good overall agreement for both type 3 and 4 studies, particularly in patients with severe OSA, there has been considerable uncertainty and ongoing debate regarding 